DOI http://dx.doi.org/10.18551/rjoas.2016-09.03

\title{
THE EFFICIENCY OF INPUT USAGE OF ORGANIC PADDY FARMING IN INDONESIA
}

\author{
Muhaimin Abdul Wahib \\ Faculty of Agriculture, University of Brawijaya, Malang, Indonesia \\ E-mail: awmuhaimin@gmail.com
}

\begin{abstract}
Organic farming is an activity in the agricultural sector which emphasizes the importance of environmental issues. Activity in this area has the objective to increase production, productivity, independence of farmers and produce high quality food. The objectives research of this study are: to analyse factors that effects the efficiency of technical input; to analyze the level of technical efficiency of input use, and to analyze the factors that influence the use of input technical inefficiency. Based on the results, the study showed that the factors have influence the efficiency of input use technically were land, seeds, manure, and organic pesticides. The average level of technical efficiency in the area was $93.3 \%$. While the factors that positively affects the level of technical inefficiency were age and number of family.
\end{abstract}

\section{KEY WORDS}

Organic farming, stochastic frontier production function, technical efficiency and inefficiency.

Organic farming became the basis of the development of farming systems that have a bright prospect in the future, especially on issues relating to environmental quality. Positive aspect for the purposes of high-quality food and nutrition can be produced by organic agricultural products. Organic farming makes farmers more professional and mature in managing the usage of inputs, they have more skill when use the inputs, as well as agriculture productivity gain, and finally slowly they can fulfil their daily needs. In Malang, especially at the Sumberpasir village, a huge number of farmers who cultivate organic paddy. Farmers in the area use production factors such as land, labor, seed, manure, compost and organic pesticides. The problem that has affected much of the area farmers is the lack of knowledge and understanding in allocating the input, therefore the organic paddy production and productivity has not been maximized. Human resource factors such as level of education, age and number of farmer's family and others, are the important factors that determine the success or failure to get high productivity level. To increase the production and productivity of organic paddy, needed the efficiency of the usage of inputs on organic paddy farming. By using frontier production function, the efficiency level and inefficiency levle of each farmer can be showed.

The objectives research of this study are: 1) To analyse factors that effects the efficiency of technical input, 2) To analyze the level of technical efficiency of input use , and 3 ) to analyze the factors that influence the use of input technical inefficiency.

\section{RESEARCH METHODOLOGY}

This research is done on purpose (purposive) at Sumberpasir Village Pakis Subdistrict Malang Regency East Java Province Indonesia. The selection of this location because of there were huge number of farmers that cultivate organic paddy. The total number of farmers that cultivate organic paddy were 37 .

This study uses primary data and secondary data. The primary data obtained through direct interviews with farmers by using a list of questions related. The secondary data obtained through government office that related with this research, such as District Office and Agriculture Department offices.

The data were analyzed using stochastic frontier production function. The production function is used to determine the factors that influence the production of organic paddy production and the level of efficiency with the technical inputs. The advantages of this 
production functions is it can detect the efficiency of each farmer. Stochastic frontier production function as follows :

$$
\operatorname{Ln} Y=\beta_{0}+\beta_{1} \ln X_{1}+\beta_{2} \ln X_{2}+\beta_{3} \ln X_{3}+\beta_{4} \ln X_{4}+\beta_{5} \ln X_{5}+v_{i}-u_{i},
$$

Where:

Y : Total Production $(\mathrm{Kg})$

$\mathrm{B}_{0}$ : Constanta

$\beta \mathrm{i}$ : Elasticity production, the production factor time-

$\mathrm{X}_{1}$ : Land area (ha)

$\mathrm{X}_{2}$ : Labor (Day work)

$X_{3}:$ Seed $(\mathrm{Kg})$

$\mathrm{X}_{4}$ : Manure $(\mathrm{Kg})$

$\mathrm{X}_{5}$ : Compost $(\mathrm{Kg})$

$\mathrm{X}_{6}$ : Organic Pesticides (ml)

$\mathrm{V}_{\mathrm{i}}$ : a symmetric, normally distributed random eror

$U_{i} \quad$ : one-side error term $\left(U_{i} \geq 0\right)$ equation:

The level of technical efficiency, mathematically formulated using the following

$$
\mathrm{TE}_{1}=\exp \left(-\mathrm{u}_{\mathrm{i}}\right)
$$

The value of TE ranges from zero to one. A value of 1 is the highest level of efficiency in relation to the use of inputs. The hypothesis was tested using Likehood value Ratio (LR). The equation used is as follows:

$$
L R=-2[\operatorname{Ln}(\operatorname{Lr})-\operatorname{Ln}(\operatorname{Lu})]
$$

Where :

LR : Likelihood Ratio

Lr : LR values in OLS

Lu : LR values in MLE equation:

Furthermore, to analyze the level of technical inefficiency will use the following

$$
\mu_{i}=\delta_{0}+\delta_{1} Z_{1}+\delta_{2} Z_{2}+\delta_{3} Z_{3}+W_{i t}
$$

Where :

$\mu_{\mathrm{i}} \quad$ : The effect of technical inefficiency

$Z_{1}:$ Age (year)

$Z_{2}$ : Education (year)

$Z_{3}$ : : Number of family (person)

\section{RESULTS AND DISCUSSION}

Based on the results analysis, can be explained that there are four factors that significantly affect the input of organic paddy production in the Sumberpasir village, Pakis subdistrict Malang regency, such as land, labor, seeds and organic pesticides. In Table 1 below we can see the whole variables or parameters that indicate the real level is as follows.

The value of gamma $(\mathrm{Y})$ of 0.96 at significance level of $5 \%$ as shown in Table 1 indicates that the error variation of confounding factors in the model is due to the technical efficiency. Squared sigma value $(\sigma)$ of 0.007 at the significance level $5 \%$ means that the effect has occurred in the technical efficiency frontier production function model. 
Table 1 - Data Analysis of Stochastic Frontier Production Function

\begin{tabular}{|c|c|c|c|c|}
\hline Variabel & Parameter & Coefisien & Standart Eror & t-ratio \\
\hline Intersep & $\beta_{0}$ & 1,73 & 1,05 & 1,65 \\
\hline Ln X ${ }_{1}$ (Land Area) & $\beta_{1}$ & 0,05 & 0,02 & $2,76^{*}$ \\
\hline Ln $X_{2}$ (Labor) & $\beta_{2}$ & $-0,001$ & 0,09 & $-0,01$ \\
\hline $\operatorname{Ln} X_{3}($ Seed $)$ & $\beta_{3}$ & 0,36 & 0,14 & $2,53^{*}$ \\
\hline Ln $\mathrm{X}_{4}$ (Manure) & $\beta_{4}$ & 0,35 & 0,11 & $3,03^{*}$ \\
\hline Ln $X_{5}$ (Compost) & $\beta_{5}$ & $-0,21$ & 0,13 & $-1,54$ \\
\hline Ln $X_{6}$ (Organic Pesticides) & $\beta_{6}$ & 0,41 & 0,12 & $3,33^{*}$ \\
\hline Sigma Squared & $\sigma$ & 0,007 & 0,001 & 5,45 \\
\hline Gamma & $\mathrm{Y}$ & 0,96 & 0,04 & 23,47 \\
\hline Log likehood function & \multicolumn{4}{|l|}{57,25048} \\
\hline LR test of the one sided error & \multicolumn{4}{|l|}{3,774587} \\
\hline${ }^{*}$ the significance level $5 \%$ & & & & \\
\hline
\end{tabular}

To see the analysis result of the hypothesis can be seen from the value of LR (Likelihood Ratio) then compared to the magnitude of the critical value $\chi_{R}^{2}$ (Kodde and Palm, 1986 ) in the amount of restriction of one. If the value result is greater than the test LR table, then the hypothesis $\mathrm{Ha}$ accepted which means on each variable used in the production process has an influence on the level of technical efficiency of input use in the level of farmers. This means that in the area of research, organic paddy farmers have not been $100 \%$ use of the technical efficiency.

Several factors in the production of organic paddy farming such as land, seed, fertilizer, and organic pesticides as indicated on the analysis results stohastic frontier production function, have the positive value, while the production factors of labor and compost are both have negative value. The value of the coefficient of the land area is 0.05 means that there will be the addition of organic paddy production of 0.05 units after the addition of the total area of one percent. This is different with factor of labor, which have negative coefficient value -0.001 . This value means that it will be decrease 0,001 in organic paddy production, when there is an additional one percent of labor. At organic farming, the intensive tillage is influence the organic paddy production, otherwise the less productive labor is less influence the organic paddy production. The use of manure in the study area are given in good portions and relatively closer to the suggestion, so that farmers are gaining additional production in accordance with the additional use of fertilizers, manure variable positive increases of 0.36 . The use of compost should be positive to increase production, it was not obtained by farmers because the applicattion time is not the right time, it makes the lack of fermentation process and make the production decline, the value of compost marked negative coefficient value is $-0,21$. The coefficient of the use of organic pesticides marked positive 0.41 , meaning farmers in the research area has brought many benefits to the use of organic pesticides to help them obtain the desired production.

The real variation of all the variables can be seen in the difference of the value t ratio with $t$ table. The Input use of land, seeds, manure and organic pesticides significant effect on the level of organic paddy production. Only inputs of labor and compost that has not significant effect on production with a significance level of $5 \%$.

Technically, the average level of efficiency which inputs of organic paddy can be seen in Table 2 below. Table 2 shows that organic paddy farmers in Sumberpasir village, Pakis subdistrict, Malang regency has a chance to increase production by 0.067 or 6.7 percent. This is can be showed from the amount of the average level of efficiency of input use technically at organic paddy farming is 0.933 .

Table 2 - The average level of efficiency in the usage of Input In The Organic Paddy Farming in Sumberpasir village, Pakis subdistrict, Malang regency

\begin{tabular}{|c|c|c|}
\hline No. & Rating Achieved & Efficiency Level \\
\hline 1 & Average & 0,933 \\
\hline 2 & Minimum & 0,837 \\
\hline 3 & Maximum & 0,987 \\
\hline
\end{tabular}


For farmers that has low level of efficiency needs to be improved, while the farmers that already have high efficiency should still be able to defend it.

If viewed as a managerial or due to nontechnical issues, the factors that affect the level of technical inefficiencies that exist in the farmers can be seen in Table 3 below:

Table 3 - Technical Inefficiency Level

\begin{tabular}{|l|c|c|c|}
\hline \multicolumn{1}{|c|}{ Variabel } & Parameter & Coefisien & t-ratio \\
\hline Intersep & $\delta_{0}$ & 0,009 & 0,08 \\
\hline$Z_{1}$ (Age) & $\delta_{1}$ & 0,0008 & 0,80 \\
\hline$Z_{2}$ (Education) & $\delta_{2}$ & $-0,005$ & $-0,92$ \\
\hline$Z_{3}$ (Number of Family) & $\delta_{3}$ & 0,01 & 1,12 \\
\hline
\end{tabular}

Table 3 above shows that the age of the farmer positive effect on the level of technical inefficiency. Increasingly older age, for farmers will increase the level of their physical inefficiency. Physically there will make lack of ability, therefore it can influence the application of new technology, new innovations will have the negative response from them. On the educational factors that has negative valur will reduce technical inefficiency farmers, higher education means that farmers can improve the efficiency with which inputs are increasingly efficien. The farmer's education can improve the long-term knowledge to cultivate the organic farming. The response to the increase in production will be higher for farmers who are well educated than the less educated. The large number of families would increase the technical inefficiency farmers themselves. Farmer needs more daily needs in a large family of farmers, they are more limited in order to obtain additional costs as a result of the increase in household expenditures, thereby affecting their technical efficiency.

\section{CONCLUSION AND SUGGESTIONS}

Based on the results of the discussion as described earlier, it can be concluded that the factors that significantly affect the level of technical efficiency are the Land Area, seeds, manure and organic pesticides. Farmers in the area of research still has a chance to improve its technical efficiency, therefore they still have a chance to obtain higher production. Several reasons that may cause farmers to have less chance to improve their organic paddy production can be solved by improving their education, both formal and informal.

The suggestion for farmer are to pay attention in the properly doziz of compost, therefore they will get good response of plants and high production as well as productivity increase. The importance of counseling for farmers is a special concern for the government, especially the department of agriculture crops to provide intensive coaching for them.

\section{REFERENCES}

1. Amarnath, J. S. and Velmurugan, S. 2015. Post-harvest losses, climate change, resource use efficiency and technical efficiency in aggregatum onion production in Tamil Nadu, India. African Journal of Agricultural Science and Technology. Vol. 3, Issue 8, pp. 384391.

2. Banani, A. Mustadjab, M. Koestiono, D, Syafrial.2013. Production Management and Technical Efficiency of Red Onion Farmingin Brebes Regency. J. Basic. Appl. Sci. Res.3(3)85-90.

3. Battese, GE. And Coelli, T.J. 1998. Prediction of firm level technical efficiencies with a generalized frontier production function and panel data. Journal of Econometrics. 38:387399.

4. Heriqbaldi, U. Purwono, R. and Primanthim, M.R. 2015. An Analysis of Technical Efficiency of Rice Production in Indonesi. Canadian Center of Science and Education. Canadian Center of Science and Education. Asian Social Science; Vol. 11, No. 3. 
5. Hidayah, I. and Susanto, A, N . 2013. Economies Of Scale And Allocative Efficiency Of Rice Farming At West Seram Regency, Maluku Province, Indonesia. Asian Economic and Social Society. 2013, 3(5):624-634.

6. Hidayat, H. 1989. Social Research Method Material. Study Program of Agribusiness Agriculture Faculty. Brawijaya University.

7. Kabore, D. P. 2014. Financial Profitability and Technical Efficiency of Horticultural crops in the Nakanbe river watershed in Burkina Faso. Vol. 6 (7). pp. 405-411.

8. Kodde, David A and Franz C. Palm. 1986. Wald Criteria for Jointly Testing Equality and Inequality Restriction. Econometrica, Volume 54, Issue 5, 1243-1248.

9. Lubis, R. Daryanto, A. Tambunan, M. and Purwanti, H. 2014. Technical, Allocative and Economic Efficiency of Pineapple Production in West Java Province, Indonesia: A DEA Approach.

10. Mallikarjun, R. M. S. Ayyanagowdar,M.Nemichandrappa,P.Balakrishnan, M. G. Patil, B. S. Polisgowdar and Satishkumar, U. 2012. Techno economic feasibility of drip irrigation for onion (Alluim cepa L). Karnataka J. Agric. Sci.,25 (4) : 475-478.

11. Ojo, M.A. Mohammed, U. S. Adeniji, B. and Ojo, A.O. 2009. Profitability and Technical Efficiency In Irrigated Onion Production Under Middle Rima Valley Irrigation Project In Goronyo, Sokoto State Nigeria.

12. Tegegne, B, Tadesse, G. And Zemedu, L .2014. Technical Efficiency In Irrigated SmallScale Agriculture: Empirical Evidence From Onion Farming In Kobo District Of Northeast Ethiopia. Journal of Agricultural Economics and Development Vol. 3(3), pp. 035-046.

13. Waryanto, B. Chozin, M.A. Dadang. Putri, E. I. K. 2014. Environmental Efficiency Analysis of Shallot Farming: A Stochastic Frontier Translog Regression Approach. Journal of Biology, Agriculture and Healthcare. Vol.4, No.19. 